\title{
AM3, an oral BRM: \\ A protective agent against \\ iatrogenic bone-marrow and liver damage in breast cancer patients under conventional adjuvant radiochemotherapy
}

\author{
Vicente G Villarrubia, PAula Marquez, Jose Cobo, Guillermo J SADA
}

\begin{abstract}
VG Villarrubia, P Marguez, J Cobo, GJ Sada. AM3, an oral BRM: A protective agent against iatrogenic bone-marrow and liver damage in breast cancer patients under conventional adjuvant radio-chemotherapy. Can J Infect Dis 1992;3(Supp1 B):138B-142B. In five clinical trials AM3, a polysaccharide/ protein biological response modifier, was given ( $3 \mathrm{~g} /$ day; two capsules, tid) to 79 breast cancer patients undergoing adjuvant radio- and/or chemotherapies. When compared with 68 control patients, AM3 provoked significant decreases in the incidence of bone-marrow hypoplasia (20.5\% versus $61.1 \%$ ). This marrow effect was also manifested in peripheral blood by higher levels of white blood cells, mononuclear cells and platelets in the AM3 treated group. The incidence of thrombocytopenia in patients receiving combined radio-chemotherapy only was $70 \%$ compared with $6 \%$ observed in patients also receiving AM3 treatment. Besides these hematological effects, AM3 palliated subclinical hepatic toxicity due to combined radio-chemotherapy. Finally, studies on acute-phase reactants, such as C-reactive protein, IgA, and factors $\mathrm{B}, \mathrm{C}_{3}^{\prime}$, and $\mathrm{C}_{5}^{\prime}$ of the complement system, suggest that a modulation of hepatic inflammatory responses by AM3 appears to be essential for clinical effects described.
\end{abstract}

Key Words: AM3, Biological response modifiers, Hemopoiesis, Inflammatory response, Liver damage

\section{AM3, un MRB oral: agent protecteur contre les lésions iatrogènes de la moelle épinière et du foie chez les patientes atteintes de cancer du sein sous radio-chimiothérapie adjuvante classique}

\begin{abstract}
RÉSUMÉ: Dans le cadre de cinq essais cliniques, l'AM3, un modificateur de la réponse biologique fait de polysaccharides/protéines a été administré à raison de 3 grammes par jour, soit 2 capsules TID, à 79 patientes atteintes de cancer du sein, sous traitement adjuvant de radio- et/ou chimiothêrapie. Par comparaison avec 68 patientes témoins, l'AM3 a provoqué des diminutions significatives de la fréquence de l'hypoplasie de la moelle osseuse $(20,5 \%$ contre $61,1 \%)$. Cet effet sur la moelle s'est également manifesté dans le sang périphérique par des taux plus élevés de globules blancs, de cellules mononucléaires et de plaquettes dans le groupe traité à l'AM3. L'incidence de thrombocytopénie chez les patientes qui recevaient un traitement combiné de radio-chimiothérapie était de $70 \%$ par rapport à $6 \%$ chez les patientes qui recevaient également de l'AM3. En plus de ces effets hématologiques, l'AM3 a réduit la toxicité hépatique subclinique attribuable à la radiochimiothérapie combinée. Finalement, les études portant sur certains marqueurs de la réaction inflammatoire tels la protéine C réactive, l'IGA et les facteurs B, C3, et C5 du système du complément, suggèrent qu'une modulation des réponses inflammatoires hépatiques par l'AM3 serait au centre des effets cliniques décrits.
\end{abstract}

Medical Department, Immunology and Oncology Section, Lab Andrómaco, Madrid, Spain

Correspondence and reprints: Dr VG Villarrubia, Immunology and Oncology Division, Medical Department, C/ Azcona 31,28028 Madrid, Spain 
$\mathrm{H}$ OST RESISTANCE AGAINST INFECTIONS IS UNDER THE control of at least three homeostatic activities: adequate hemopoiesis; capacity of cells to reach inflammatory sites (tissue cell distribution); and ability of these mobilized cells to destroy germs and/or germ-infected cells. These activities are regulated by mechanisms which involve cell to cell as well as cellcytokine interactions. Although complex and not well understood, in the majority of cases these intermediate interactions are the consequence of initial events in which the 'acute inflammatory response' plays an essential role. The acute inflammatory response is put into play by the liver in response to noxious agents (bacteria, viruses, fungi and chemical and physical trauma) and manifested by changes in the protein and metal composition of serum and modifications - sometimes surreptitious - within the immune and hemopoietic compartments. It is generally thought that the acute inflammatory response, when controlled, is beneficial for the host (1-3).

Many of the above-cited agents - including cancer (4) - as well as some new therapeutic procedures (5) alter the acute inflammatory response, thus modifying this rapid and efficacious mechanism of host resistance while inducing side effects.

Attempting to palliate some of these disturbances, the authors initiated treatment of immunocompromised patients with AM3 (Immunoferon; Lab Andrómaco, Spain) some years ago. AM3 is a polysaccharideprotein compound adsorbed into an inorganic matrix of calcium phosphate-sulphate. The polysaccharide is a $\beta$ 1-6, $\beta$ 1-3 gluco-mannan isolated by fermentative procedures from the cell wall of a Candida utilis strain. The protein belongs to the nutrient component of the ricin seed. Pharmacologically, AM3 has been defined as a second signal biological response modifier because of its modulating properties on previously altered hosts (6). In this sense, AM3 appears to amplify the natural reactivities mise-en-scène in response to the noxa. Among a myriad of actions, AM3 enhances macrophage $(7,8)$ and natural killer $(8,9)$ activities, induces tissue cell distribution and improves hemopoiesis (10).

This paper summarizes the results obtained in five clinical trials performed in breast cancer patients (Table 1) (11-13). The interpretation of these trials lead to the suggested existence of an hepatoimmuno hemo- poietic circuit (3) whose conservation and/or modulation by AM3 appears to be essential for providing an adequate host resistance with minimal side effects.

\section{PATIENTS AND TREATMENT}

A total of 147 women diagnosed with breast cancer were studied. Ages ranged from 28 to 71 years old. Tumour stages were $\mathrm{T}_{2}-\mathrm{T}_{3 \mathrm{~A}} \mathrm{~N}^{+}$Mo except in one study (13) who were $T_{1}, T_{2 A}-T_{2 B}$ No Mo. After diagnosis, all patients underwent mastectomy and two to three weeks later they underwent adjuvant therapies. Eighty-six patients received locoregional radiotherapy (56 and 50 Gy over five to six weeks) together with a conventional chemotherapy protocol of: cyclophosphamide 600 $\mathrm{mg} / \mathrm{m}^{2}$ intravenously day 1 ; methotrexate $40 \mathrm{mg} / \mathrm{m}^{2}$ intravenously on day 1 ; and 5-fluorouracil $600 \mathrm{mg} / \mathrm{m}^{2}$ intravenously on day 1 . All 86 patients received at least three chemotherapy cycles before evaluation. Fifteen patients underwent only adjuvant radiotherapy at the doses described above, and 26 underwent the same radiotherapy protocol plus at least five chemotherapy cycles with doxorubicin $50 \mathrm{mg} / \mathrm{m}^{2}$ intravenously, day 1 and cyclophosphamide $600 \mathrm{mg} / \mathrm{m}^{2}$ intravenously, day 1. Finally, 20 patients received five cycles of doxorubicin/cyclophosphamide. In summary, the control group was 68 patients and the AM3 group 79 patients (Table 1). For each trial both arms of treatment were homogeneous at baseline with regard to age, tumour stage and bone marrow and hematological status.

Hematological studies: Before and after therapies all patients underwent bone marrow aspirates to evaluate marrow cellularity. In all trials, the number of white blood cells, polymorphonuclear leukocytes, mononuclear cells, platelets and red blood cells were recorded twice monthly (in the nadir of chemotherapy and before the subsequent cycle). For each trial, blood samples were collected at the same time in both arms.

Functional hepatic parameters: In one trial the levels of aspartate aminotransferase (AST), alanine aminotransferase (ALT), gamma glutamyl transferase (GGT), lactate dehydrogenase (LDH), copper and iron were measured at baseline and monthly during treatments by automated chemical analysis using standard reagents (unpublished data).

Acute-phase reactants: In one trial (13), levels of Creactive protein, ceruloplasmin, immunoglobulin A (IgA)

\section{TABLE}

Summary of trials performed with $\mathrm{AM}^{*}$ in breast cancer patients under adjuvant oncologic therapies

\begin{tabular}{|c|c|c|c|c|}
\hline Reference & Assay type & $\begin{array}{l}\text { Number of patients } \\
\text { (control versus AM3) }\end{array}$ & Conventional treatments & $\begin{array}{c}\text { Duration of AM3 treat- } \\
\text { ment (months) }\end{array}$ \\
\hline Milla et al (11) & Open-controlled & 20 versus 26 & A-RCT & 9 \\
\hline Villarrubia et al (12) & Double-blind & 20 versus 20 & A-RCT & 3 \\
\hline Unpublished data & Double-blind & 12 versus 14 & A-RCT & 5 \\
\hline Unpublished data & Double-blind & 11 versus 09 & $\mathrm{~A}-\mathrm{CT}$ & 5 \\
\hline Garcia et al (13) & Open-controlled & 05 versus 10 & A-RT & 1 \\
\hline
\end{tabular}

$3 \mathrm{~g} /$ day AM3 is given as 2 capsules tid. A-CT Adjuvant chemotherapy: A-RCT Adjuvant radio-chemotherapy; A-RT Adjuvant radiotherapy 
TABLE 2

Incidence of bone marrow hypoplasia and leukocyte and platelet nadirs in breast cancer patients under adjuvant cytotoxic therapies - effects of treatment with AM3

\begin{tabular}{|c|c|c|c|c|c|c|}
\hline \multirow[b]{2}{*}{ Trial (reference) } & \multicolumn{2}{|c|}{ Bone marrow hypoplasia } & \multicolumn{2}{|c|}{ White blood cell nadir $\left(x \mathrm{~mm}^{3}\right)$} & \multicolumn{2}{|c|}{ Platelets nadir ( $x \mathrm{~mm}^{3}$ ) } \\
\hline & Control & AM3 & Control & AM3 & Control & AM3 \\
\hline A-RCT (11) & $13 / 20(65)$ & $7 / 26(26.9)^{* * *}$ & 1900 & 4000 & 70,000 & 120,000 \\
\hline A-RCT (12) & $14 / 19(73.6)$ & $2 / 19(10.5)^{* * * *}$ & 2000 & 4100 & 90,000 & 140,000 \\
\hline A-RCT (Unpublished data) & $8 / 12(66.6)$ & $4 / 14(28.5)^{*}$ & 800 & 1100 & 59,000 & 98,000 \\
\hline A-CT (Unpublished data) & $3 / 11(27.2)$ & $1 / 9(11.1)$ & 300 & 1700 & 107,000 & 116,000 \\
\hline A-RT (13) & $3 / 5(60)$ & $2 / 10(20)$ & 4700 & 6600 & 220,000 & 290,000 \\
\hline
\end{tabular}

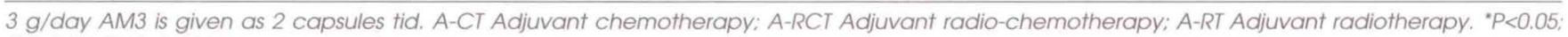
${ }^{*} P<0.01 ; \cdots P<0.001$ versus control

and complement factors $\left(\mathrm{C}_{3}^{\prime}, \mathrm{C}_{5}^{\prime}\right.$ and factor $\left.\mathrm{B}\right)$ were measured at baseline and weekly during radiotherapy. Values were compared with those obtained in 10 healthy controls. C-reactive protein, complement components and IgA were evaluated by conventional radial immunodiffusion procedures.

Statistical analysis: For each trial, quantitative values (mean $\pm \mathrm{SD}$ ) were analyzed by the Student's $t$ test. For qualitative values, a comparison of percentages was applied. A global comparison has been done in order to evaluate only bone marrow hypoplasia incidence.

\section{RESULTS}

Hematological studies: The incidence of mild to moderate bone marrow hypoplasia in the control group oscillated from 65 to $73.6 \%$ in patients who underwent combined treatment (adjuvant radio-chemotherapy) $60 \%$ in patients undergoing adjuvant radiotherapy and $27.2 \%$ in patients undergoing chemotherapy alone (Table 2). In the AM3-treated group, the incidence of hypoplasia was significantly lower for patients receiving radio-chemotherapy but not for chemotherapy or radiotherapy patients; however, the lack of statistical significance may be related to the small number of patients. The global incidence of marrow hypoplasia was $61.1 \%$ in the control groups versus $20.5 \%$ in the AM3-treated groups $(\mathrm{P}<0.001)$. As shown in Table 2 , in all trials, nadirs of white blood cells and platelets were lower in the control groups, compared with their respective AM3treated arms. Moreover, 28 of 40 patients (70\%) in the global control group developed mild to moderate thrombocytopenia versus three of $45(6 \%)$ in the AM3 group when radio-chemotherapy was applied (Table 3 ).

Figure 1 shows the evolutive pattern of polymorphonuclear leukocytes in patients who underwent adjuvant chemotherapy.

Statistically significant differences among control and AM3 groups were found at the fourth $(\mathrm{P}<0.01)$, sixth $(\mathrm{P}<0.05)$, seventh $(\mathrm{P}<0.01)$ and eighth $(\mathrm{P}<0.001)$ cycles of the study as well as at one month after chemotherapy withdrawal. Similar changes were observed (Table 3) in patients undergoing radiochemotherapy). However, patients receiving radiochemotherapy exhibited significantly lower peripheral blood
TABLE 3

Effects of AM3 treatment on peripheral blood mononuclear cell (PBMNC) levels and incidence of thrombocytopenia in breast cancer patients under adjuvant therapies

\begin{tabular}{|c|c|c|c|c|}
\hline \multirow{2}{*}{$\begin{array}{l}\text { Adjuvant } \\
\text { treat- } \\
\text { ments }\end{array}$} & \multirow[b]{2}{*}{ Group } & \multicolumn{2}{|c|}{$\begin{array}{l}\text { Mean } \pm \text { SD PBMNC } \\
\text { levels }\left(\times 10^{\circ} / \mathrm{L}\right)\end{array}$} & \multirow{2}{*}{$\begin{array}{l}\text { Thrombocytopenic } \\
\text { incidence }\end{array}$} \\
\hline & & Baseline & Final & \\
\hline \multirow[t]{2}{*}{ A-CT } & Control & $\begin{array}{c}2.56 \pm \\
0.73 \\
(n=14)\end{array}$ & $\begin{array}{c}1.58 \pm \\
0.27 \\
(n=8)\end{array}$ & \\
\hline & AM3 & $\begin{array}{c}2.56 \pm \\
0.73 \\
(n=14)\end{array}$ & $\begin{array}{l}2.09 \pm \\
0.31^{*} \\
(n=6)\end{array}$ & \\
\hline \multirow[t]{2}{*}{ A-RCT } & Control & $\begin{array}{c}1.94 \pm \\
0.54 \\
(n=20)\end{array}$ & $\begin{array}{c}0.99 \pm \\
0.67^{\dagger} \\
(n=20)\end{array}$ & $28 / 40(70 \%)^{* * *}$ \\
\hline & AM3 & $\begin{array}{c}2.16 \pm \\
0.33 \\
(n=19)\end{array}$ & $\begin{array}{c}2.10 \pm \\
0.67^{* * *} \\
(n=19)\end{array}$ & $3 / 45(6 \%)^{* * *}$ \\
\hline
\end{tabular}

${ }^{*} P<0.01 ; \cdots P<0.001$ versus control; ${ }^{t} P<0.01$ versus chemotherapy; $A-C T$ Adjuvant chemotherapy; A-RCT Adjuvant radio-chemotherapy

mononuclear values than those receiving chemotherapy alone $(\mathrm{P}<0.01)$ (Table 3$)$.

Functional hepatic parameters: Seven of 23 control patients (30\%) developed abnormalities in AST and GGT levels, while eight (34\%), 14 (60\%) and 10 (43\%), respectively, had abnormal ALT, LDH and copper values when radio- and/or chemotherapy was given (Table 4) (unpublished data). In contrast none of the patients in the AM3-treated groups showed AST alterations and only two $(8 \%)$ and three $(13 \%)$ had ALT and GGT abnormalities

Acute-phase reactants: Table 5 summarizes results concerning $\mathrm{C}$-reactive protein, IgA and factors $\mathrm{B}, \mathrm{C}_{3}$, and $\mathrm{C}_{5}$, of the complement system. Adjuvant radiotherapy (control group) did not modify the baseline levels in any case. However, associated treatment with AM3 significantly increased C-reactive protein $(\mathrm{P}<0.001)$ but diminished IgA $(\mathrm{P}<0.001)$, factor $\mathrm{B}$ $(\mathrm{P}<0.05), \mathrm{C}_{3}^{\prime},(\mathrm{P}<0.05)$ and $\mathrm{C}_{5}^{\prime},(\mathrm{P}<0.01)$.

\section{DISCUSSION}

Hematological parameters: It is well known that anticancer radio- or chemotherapy affects hemopoiesis (14. 


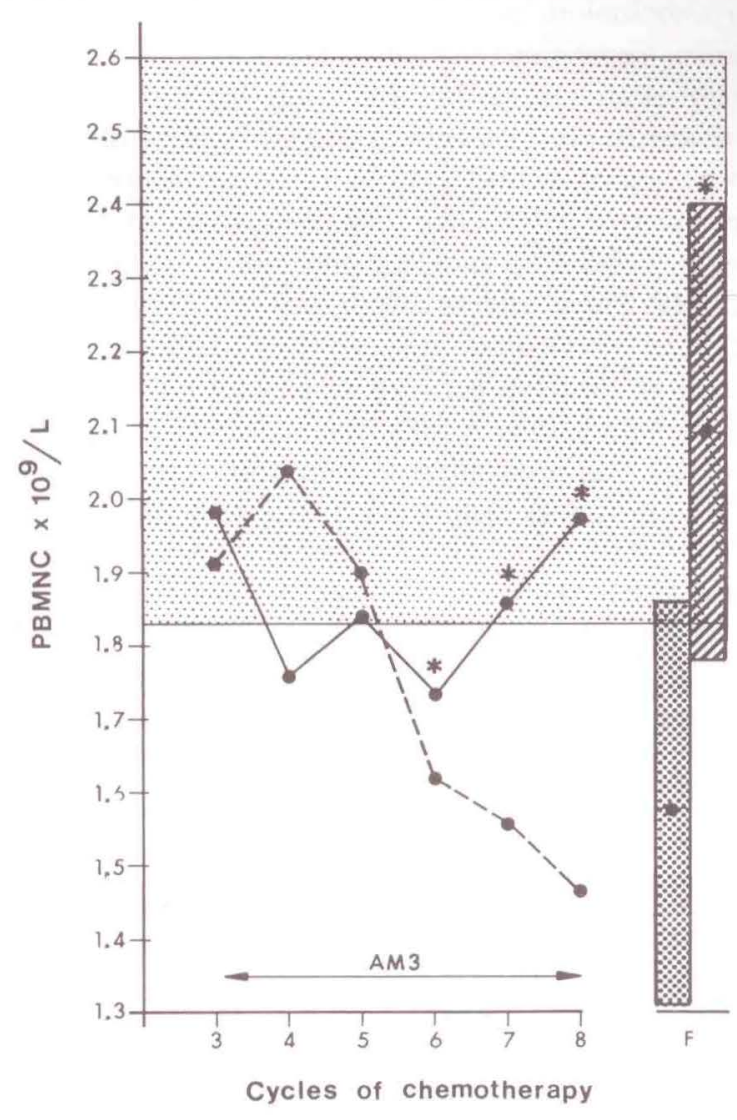

Figure 1) Evolutive pattern of peripheral blood mononuclear cells $\left(\times 10^{9} / L\right)$ in breast cancer patients undergoing adjuvant chemotherapy with (solid line) or without (broken line) AM3 treatment. F Final results (one month after stopping chemotherapy); AM3-treated patients; Control; *Significant versus control: Values at baseline

6). These effects are manifested by bone marrow hypoplasia and low levels of white blood cells and platelets, among others. The intensity of hemopoietic damage is greater in patients undergoing combined adjuvant radio-chemotherapy. Patients receiving radiochemotherapy showed a higher incidence of bone marrow hypoplasia (Table 2) and lower levels of peripheral blood mononuclear and platelets (Tables 2,3) than patients receiving chemotherapy alone. AM3 treatment clearly palliated the hematological alterations indicating that AM3 has hemopoietic activities in humans. These activities were manifested in patients undergoing radiotherapy and/or chemotherapy as higher levels of peripheral blood mononuclear cells and platelets. The majority of colony stimulating factors (CSFs) affect the granulocyte/monocyte line $(17,18)$; however, only interleukin (IL)-1 (19) and IL-3 (20) in humans, and IL-6 (21) in mice have consistent effects on platelet production. IL- 1 and IL- 6 are the principal mediators of the inflammatory response $(1,22)$ and AM3 appears to regulate them positively $(3,13)$; therefore, the hemopoietic effects of AM3 might result from an enhancement in the production of IL-1 and IL-6.
TABLE 4

Effects of AM3 treatment on number of patients showing abnormalities and absolute values of some functional hepatic parameters (FHP) in breast cancer patients who had radio- and/or chemotherapy

\begin{tabular}{lcccc}
\hline $\begin{array}{l}\text { FHP } \\
\text { (normal) }\end{array}$ & \multicolumn{2}{c}{ Control } & \multicolumn{2}{c}{ AM3 } \\
\hline AST & $54 \pm 8$ & $72.28 \pm 20.40$ & - & - \\
$(9-43$ IU/L) & $(2)$ & $(7)$ & $(0)$ & $(0)^{* *}$ \\
ALT & $68.5 \pm 1.5$ & $93.62+43.24$ & $54.5 \pm 5.5$ & $60 \pm 2$ \\
$(9-43$ IU/L) & $(2)$ & $(8)$ & $(2)$ & $(2)$ \\
GGT & $72.33 \pm 9.87$ & $109.71 \pm 50.74$ & - & $76.33 \pm 5.24$ \\
$(14-55$ IU/L) & $(3)$ & $(7)$ & $(0)$ & $(3)$ \\
LDH & $349.66 \pm 43.27374 .5 \pm 45.78$ & $348.2 \pm 39.71$ & $332.28 \pm 37.79$ \\
$(99-285$ & $(6)$ & $(14)$ & $(5)$ & $(14)^{*}$ \\
IU/L) & & & & \\
CU & $175.8 \pm 5.91$ & $188 \pm 27.50$ & $175.42+8.20$ & $187.77 \pm 15.33$ \\
$(65-165$ & $(5)$ & $(10)$ & $(7)$ & $(9)$ \\
Hg/L) & & & &
\end{tabular}

In all cases the number of patients studied was 23. " $P<0.05 ; * P<0.01$ versus control. ALT Alanine aminotransferase; AST Aspartate aminotransferase: Cu Copper; GGT Gamma glutamyl transferase; LDH Lactate dehydrogenase

With regard to peripheral blood mononuclear levels the following should be considered: Breast cancer patients undergoing adjuvant radiotherapy have low lymphocyte counts after radiation $(23,24)$. As shown previously (12) and herein (Table 3), treatment with AM3 avoids peripheral blood mononuclear cell decreases provoked by radio-chemotherapy. Besides the well known immune activities, peripheral blood mononuclear cells play an important role in resistance to infections through the secretion of endogenous CSFs (17). A recent trial (personal communication) showed a lower incidence and severity of infections in nonHodgkin's lymphoma patients under aggressive chemotherapy with AM3. The clear effect of AM3 on peripheral blood mononuclear cell levels could provide a source of these cells to perform an ulterior peripheral blood stem cell autografting after marrow ablative therapies (25).

Functional liver abnormalities: In addition to bone marrow damage, chemotherapy provokes subclinical hepatic toxicity manifested by alterations of liver enzymes (26). This (Table 4) and other studies (unpublished data) show that these alterations are also observed in patients who received a combination of radio-chemotherapy; however, treatment with AM3 decreased these hepatic alterations. The activity of AM3 on liver enzymes has been also reported in patients with chronic active hepatitis B (27). ALT normalization was accompanied with $\mathrm{HBe}$ antigen and HBV-DNA clearances together with intriguing evolutive changes in peripheral blood mononuclear cells (28).

Acute-phase reactants: Cancer patients frequently show alterations in inflammatory response manifested by decreases in IL-1 production (29) and monocyte chemotaxis (4), and increases in some complement factors $(30,31)$. The present study shows that breast 
cancer patients at the initial stages of their illness tend to show higher serum levels of IgA and factors $\mathrm{B}, \mathrm{C}_{3}$ and $\mathrm{C}_{5}$ of the complement system than healthy controls while C-reactive protein remains normal. Radiotherapy does not modify these acute phase reactants but treatment with AM3 significantly increases C-reactive protein while diminishing IgA and complement factors. Although discussed elsewhere (13), data concerning C-reactive protein clearly shows the ability of AM3 to initiate an acute inflammatory response. C-reactive protein production is under the control of IL-1 and IL-6 $(22,32)$; their hemopoietic roles have been discussed above.

\section{REFERENCES}

1. Dinarello CA. Cytokines: Interleukin-1 and tumor necrosis factor (cachectin). In: Gallin JI, Goldstein IM, Snyderman $\mathrm{R}$, eds. Inflammation. Basic principles and clinical correlates. New York: Raven Press Ltd, 1988:195-208.

2. Helfgott DC, Tatter SB, Santhanam U, et al. Multiples forms of b2 /IL-6 in serum and body fluids during acute bacterial infection. J Immunol 1989;142:948-53.

3. Villarrubia VG, Herrerias JM, Valladolid JM, et al. Inflammatory response, haemopoiesis and chronic B hepatitis. Gastroenterol Hepatol 1990;13:264-65.

4. Cianciolo GJ, Hunter J, Silva J, et al. Inhibitors of the monocyte response to chemotaxins are present in human cancerous effusions and react with monoclonal antibodies to the P15E structural protein of retroviruses. $\mathrm{J}$ Clin Invest 1981;69:831-44.

5. Jablons DM, Mule JJ, McIntosh JK, et al. IL-6/IFN-b-2 as a circulating hormone. Induction by cytokine administration in humans. J Immunol 1989; 142:1542-7.

6. Villarrubia VG, Lopez Elorza F, Sada G, et al. AM3: A second signal BRM. Its use in bone-marrow depression and chronic viral infectious. EOS - J Immunol Immunopharmacol 1990;10:227-8.

7. Cañavate ML, Ponton J, Amurrio C, et al. Efecto de un nuevo inmunomodulador sobre la funcionalidad de macrofagos de raton. Rev Clin Esp 1984;3:159-62.

8. Villarrubia VG, Sada G, Luini W, Sozzani S, Spreafico F. Restauración por AM3 de la actividad citotóxica antitumoral de células NK y macrófagos en animales inmunocomprometidos. Oncologfa 1987;10:283-91.

9. Moya P, Baixeras E, Barasoain I, et al. Inmunoferén (AM3) enhances the activities of early-type interferon inducers and natural killer cells. Inmunopharmacol Immunotoxicol 1987;9:243-56.

10. Villarrubia VG. Aproximación terapéutica con modificadores de la respuesta biológica. Consideraciones al tratamiento con AM3. En: Symp. Inmunol y Dermatol. Jarpyo edic. Madrid 1987:49-58.

11. Milla A, Sanchiz F, Sada G, Villarrubia VG. Bone-marrow recuperation by AM3 in breast cancer patients submitted to aggressive adjuvant treatment. A preliminary report. Anticancer Research 1986;6:865-8.

12. Villarrubia VG, Sada G, Marquez P, Doseretz B, Rosetti I, Levy DE. Spontaneous and AM3-induced bone-marrow recovery after radio-chemotherapy arrest seem to depend on levels of peripheral blood mononuclear cells. Int $J$ Immunother 1988;IV:177-85.

13. Garcia de Villaescusa R, Otero R, Sada G, Villarrubia VG. Inflammatory and haematologic responses in breast cancer patients under adjuvant radiotherapy (A-RT). Anticancer Res 1990;10:A262.

14. Lohrmann HP, Schreml W, Lang M, Betzler M, Fliedner TM, Heimpel H. Changes of granulopoiesis during and after adjuvant chemotherapy of breast cancer. Br J Haematol 1978;40:369-81.

15. Scherml W, Lohrmann HP, Anger B. Stem cell defects after cytoreductive therapy in man. Exp Haematol
In conclusion, AM3 administered to breast cancer patients receiving adjuvant treatment with radiotherapy plus chemotherapy, with cyclophosphamide and doxorubicin, protects against iatrogenically induced bone marrow and liver alterations. Moreover, the bone marrow protective effect is also observed in patients receiving radiotherapy plus chemotherapy with CMF. These effects are manifested by increases in peripheral blood mononuclear in all trials, and by increases in platelet counts in patients submitted to radio-chemotherapy (CMF). Therefore, AM3 potentially modulates the production of cytokines engaged in the host inflammatory response (IL-1 and IL-6).

1985;13:31-42.

16. Testa NG, Hendry JH, Molineux G. Long-term bone-marrow damage in experimental systems and in patients after radiation or chemotherapy. Anticancer Res 1985;5:101-10.

17. Metcalf $\mathrm{D}$. The role of the colony-stimulating factors in resistance to acute infections. Immunol Cell Biol 1987;65:35-43.

18. Groopman JE. Clinical applications of colony-stimulating factors. Semin Oncol 1988; 15:27-33.

19. Tewari A, Buhles WC Jr, Starnes HF Jr. Preliminary report: Effects of interleukin-1 on platelet counts. Lancet 1990;336:712-4.

20. Gaser A, Lindermann A, Seipelt G, et al. Effect of recombinant human interleukin-3 (rh IL-3) in patients with bone-marrow failure. A phase I/II trial. Blood 1989;74:50. (Abst)

21. Hill RJ, Warren MK, Levin J. Stimulation of thrombopoiesis in mice by human recombinant interleukin-6. $\mathrm{J}$ Clin Invest 1990;85:1242-7.

22. Gauldie J, Northemann W, Fey GH. IL-6 functions as an exocrine hormone in inflammation. Hepatocytes undergoing acute phase responses require exogenous IL-6. J Immunol 1990; 144:3804-8.

23. Stjernsward J. Can survival be decreased by postoperative irradiation? Int J Radiat Oncol Biol Phys 1977;2:1171-5

24. Shukla HS, Hugues LE, Whitehead RH, Newcombe RG. Long-term follow-up of general immune competence in breast cancer. II. Sequential pre- and post-treatment levels: A 10 year study. Cancer Immunol Immunother 1986;21:6-11.

25. Villarrubia VG, Sada G. Intensive chemotherapy followed by bone-marow autotransplant. Med Clin (Bar) 1990;94:518-9.

26. Larroquette CA, Hortobagyi GN, Buzdar AU, Holmes FA. Subclinical hepatic toxicity during combination chemotherapy for breast cancer. JAMA 1986;256:2988-90.

27. Herrerias JM, Valladolid JM, Villarrubia VG, et al. Antiviral and immunohematologic effects of AM3 in patients with chronic active Hepatitis B: A pilot study in 13 patients. Curr Ther Res 1991;49:566-74.

28. Elorza FL, Valladolid JM, Vilchez JG, et al. Immunomodulatory activities of AM3 appear to be related with its positive effects on chronic type B hepatitis. J Hepatol 1990;11(Suppl 2):S86.

29. Herman J, Knew MC, Rabson AR. Defective interleukin-1 production by monocytes from patients with malignant diseases: Interferon increases IL- I production. Cancer Immunol Immunother 1984;16:182-5.

30. McKenzie D, Colsky J, Hetrick DL. Complement reactivity of cancer patients: Measurements by immunehemolysis and immuneadherence. Cancer Res 1967;27:2386-99.

31. Lamoreaux G, Mandeville R, Poisn R, et al. Biological markers and breast cancer. A multiple parametric study: Increased serum protein levels. Cancer 1982;49:502-12.

32. Li SP, Liu TY, Goldman ND. Identification of the cisacting elements responsible for $\mathrm{C}$-reactive protein gene expression. FASEB J 1988;2:A1246.2. 


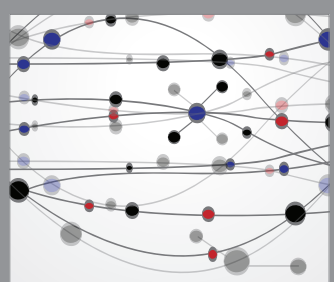

The Scientific World Journal
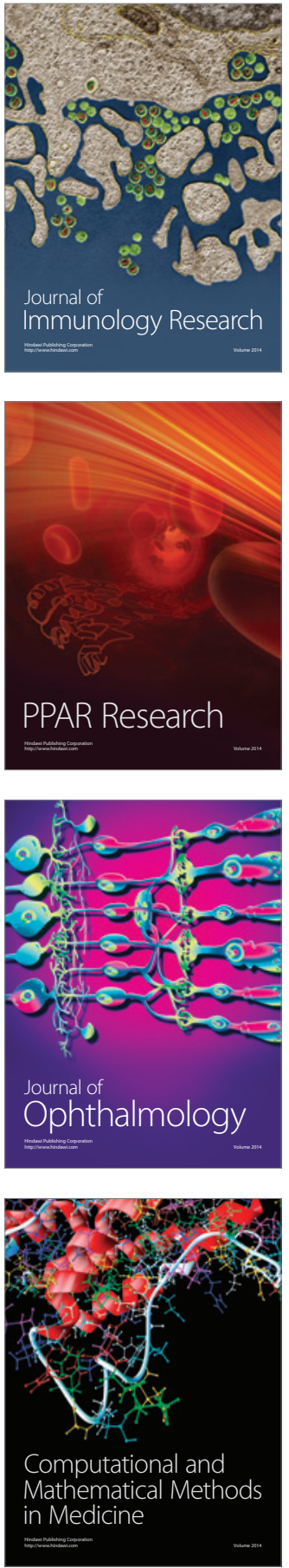

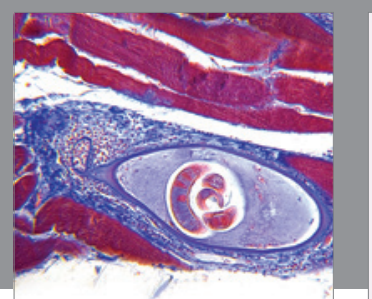

Gastroenterology Research and Practice

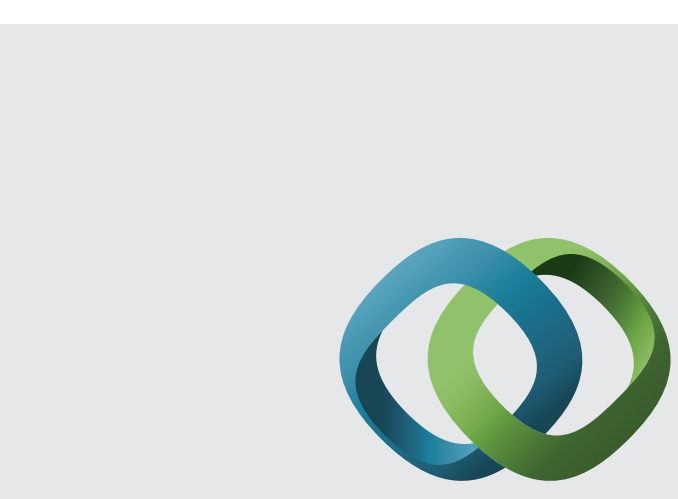

\section{Hindawi}

Submit your manuscripts at

http://www.hindawi.com
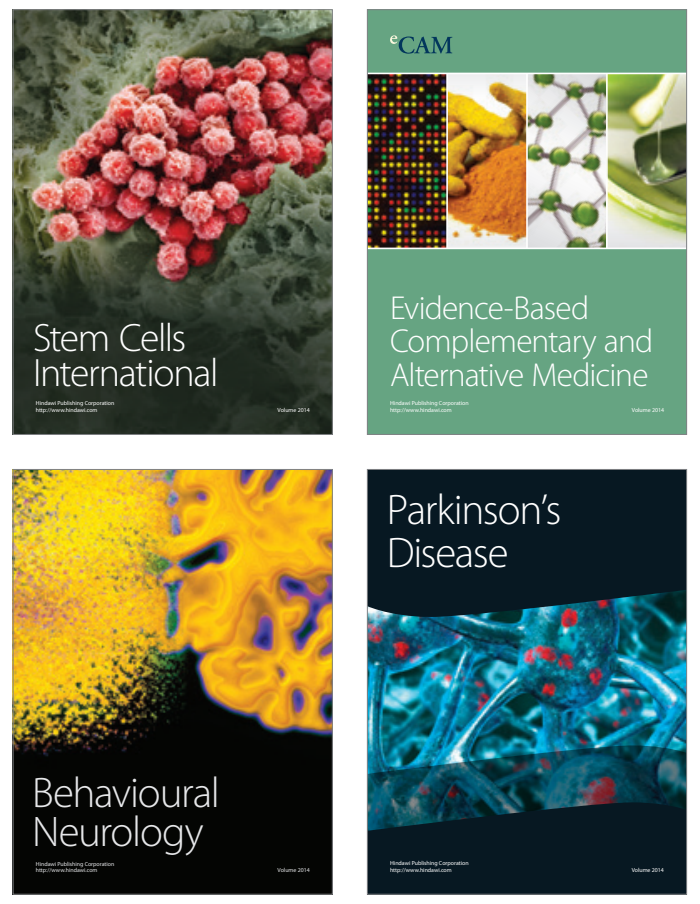
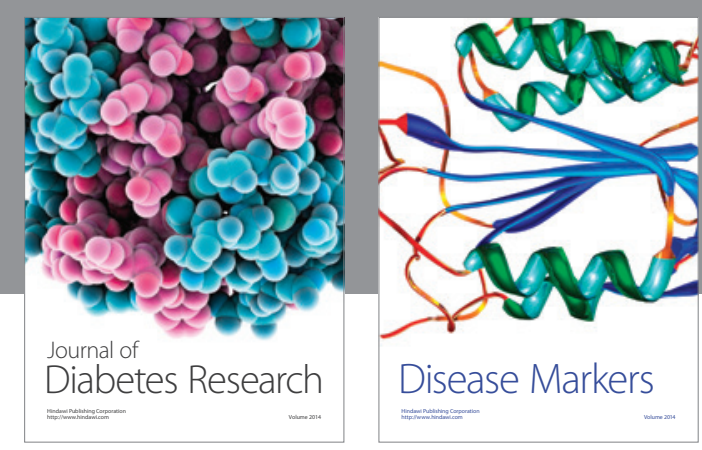

Disease Markers
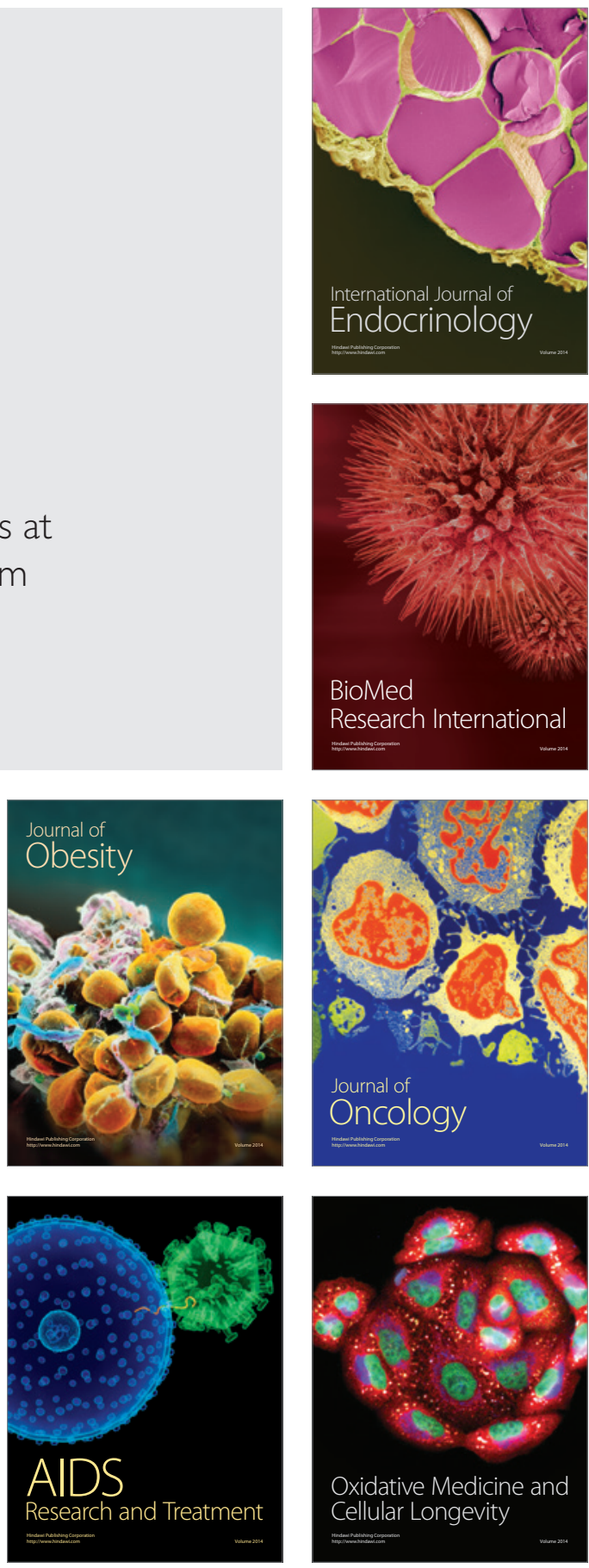